\title{
Blended Media Sinkronus dan Asinkronus untuk Meningkatkan Hasil Belajar Siswa di Sekolah Dasar
}

\author{
Tera Noviantiningtyas Ripto Saputri \\ Universitas Nusantara PGRI Kediri \\ teranovianti114@gmail.com \\ Cecilia Permatasari \\ SDN Mojoroto 4 Kota Kediri \\ permatasari@gmail.com \\ Bagus Amirul Mukmin \\ Universitas Nusantara PGRI Kediri \\ bagusamirulm@gmail.com
}

\begin{abstract}
The Covid-19 pandemic has had a significant impact on all sectors, one of which is the education sector, namely elementary schools. The impact of the pandemic has made student learning outcomes decline because many teachers only use WhatsApp as a online learning medium. For this reason, there must be different learning innovations during the pandemic to be able to improve student learning outcomes. This innovation can be in the form of using synchronous Blended Media and Asynchronous Media on the theme of the area where I live in class IV Mojoroto 4, Kediri City. This research is a classroom action research with 4 stages starting from planning, implementing, observing, and reflecting. This research instrument uses a test sheet given to students. The results in this study there was a significant increase in student learning outcomes in cycle 3, marked by $86 \%$ of students scoring above the KKM and 14\% below the KKM. Therefore, it can be concluded that there is an increase in student learning outcomes towards the use of synchronous and asynchronous blended media.Abstract adalah ringkasan isi artikel yang memuat poin-poin penting setiap komponen artikel.
\end{abstract}

Keywords: Learning outcomes, Synchronous media, Asynchronous media.

\section{Pendahuluan}

Pada tahun 2020 mulailah keadaan di mana bisa dikatakan dengan masa sulitnya semua negara diberbagai sektor baik dalam sektor ekonomi maupun pendidikan. Kesulitan itu dihadapi oleh semua negara khususnya Indonesia. Indonesia juga merasakan kesulitan karena adanya pandemi. Kesulitan itu karena adanya Covid-19 (Corona Virus Disease) atau disebut dengan virus corona. Sejak tahun 2020 WHO menetapkan virus corona sebagai pandemi. Sejak adanya covid-19 pada sektor pendidikan dapat merubah kebijakan dari kurikulum pendidikan hingga teknis dalam dunia pendidikan. Hal ini diperkuat dengan adanya surat pengeluaran dari Badan Nasional Penanggulanan Bencana (BNPB) terkait adanya masa darurat adanya virus corana. Begitu juga surat pengeluaran dari Menteri Pendidikan dan Kebudayaan nomor 36962/MPK.A/HK2020 pada tanggal 17 Maret 2020 tentang pembelajaran yang dilakukan di dalam rumah masing-masing dengan adanya pembelajaran yang dilaksanakan dengan daring atau dilakukan secara online karena adanya penyebaran virus corona. Dengan adanya surat pemberitahuan tersebut semua sekolah melakukan pembelajaran secara daring. Banyak ruang aplikasi yang bisa dijadikan 
sebagai penunjang kegiatan pembelajaran daring seperti aplikasi berbasis E-learning yaitu Zoom, WhatsAap, Email, Edmodo, Google Classroom, dan Google Meet.

Namun kenyataannya meskipun banyak ruang aplikasi online dan kuota internet yang diberikan pemerintah yang bisa dijadikan berlangsungnya proses pembelajaran belum digunakan secara baik. Dalam pembelajaran daring ini banyak sekolah yang hanya menggunakan media WhatsApp sebagai alat yang digunakan untuk berlangsungnya suatu pembelajaran. Diperkuat dengan (Lestari, 2021) bahwa, banyak yang menggunakan media WhatsApp dikalangan pelajar karena bisa mengirim akses chatting, foto, video, dll. Selain itu, penggunaan WhatsApp ini dikarenakan sangat mudah dan lebih terkenal karena lebih murah serta praktis digunakan. Penggunaan inipun dikarenakan banyak siswa, orangtua, bahkan guru yang masih kurang paham dalam penggunaan teknologi. Diperkuat dengan pernyataan (Santaria, 2020) bahwa banyak guru yang masih kurang kemampuan dalam penggunaan teknologi. Seharusnya, guru harus lebih menguasai sehingga dapat dikatakan sebagai tuntutan dalam pembelajarn daring ini. Di sisi lain penggunaan media WhatsApp ini terdapat beberapa kekurangan. Diperkuat dengan pernyataan Yensy dalam (Lestari, 2021) adalah sinyal suatu daerah yang berbeda, chat yang menumpuk pada WhatsApp membuat memori menjadi penuh, dengan chat yang menumpuk sehingga membuat kebingungan untuk mencari chat yang digunakan sebagai ruang diskusi.

Berdasarkan observasi pada SDN Mojoroto 4 Kota Kediri pada kelas IV peneliti mendapatkan hasil bahwa saat pembelajaran dilakukan hanya dengan menggunakan WhatsApp. Dengan menggunakan WhatsApp ini dapat menyebabkan beberapa kekurangan di antaranya adalah terdapat pada hasil belajar siswa yang turun karena keadaan pandemi ini yang siap tidak siap harus tetap melaksanakan pembelajaran walau dengan daring. Sebelum penelitian diketahui bahwa presentase siswa yang belum lulus KKM sebanyak 12 atau 57\% siswa dan 9 siswa atau $43 \%$ yang sudah lulus KKM. Menurut guru kelas IV alasan banyak yang menggunakan WhatsApp adalah banyak guru, orangtua, dan murid yang belum pandai terhadap teknologi, banyak yang belum mempunyai gadget, terbatasnya material atau keuangan selama pandemi untuk membeli kuota internet, dll. Sementara itu, menurut (Adi et.al, 2021) juga memiliki dampak negatif selama pandemi di antaranya adalah daerah yang masih kekurangan akses internet, pembelajaran yang belum bisa kolaboratif dan kerjasama sehingga begitu terbatas, pembelajaran yang sebenarnya masih memerlukan pendamping sehingga jika belum adanya pendamping pembelajaran belum bisa berjalan secara maksimal, adanya kerusakan mata atau yang lain terhadap kesehatan karena terlalu seringnya melihat layar gadget.

Dengan beberapa kendala dalam penjelasan di atas sebagai solusi SDN Mojoroto 4 Kota Kediri ini dapat menggunakan aplikasi online yaitu menggabungkan/ blended media sinkronus berupa aplikasi zoom dan media asinkronus sebagai mengerjakan tugas seperti google classroom, quisis, google form, dll untuk menunjang pembelajaran khususnya pada kelas IV. Pembelajaran semacam ini yang digunakan saat pandemi covid-19 sedang berlangsung di sekolah dasar. Diperkuat dengan pernyataan (Amadea, 2020), bahwa pembelajaran sinkronus dilaksanakan dengan menggunakan internet pada waktu yang sama. Melibatkan peserta didik dan pendidik secara langsung dalam kegiatan virtual atau online sehingga dapat menjelaskan materi secara langsung. Kemudian untuk media sinkronus sebagai bahan evaluasi guna mengerti kepahaman siswa.

Tujuan dari penelitian ini adalah untuk mengetahui penggunaan Blended Media Sinkronus dan Media Asinkronus, untuk mengetahui peningkatan hasil belajar dengan menggunakan blended media di SDN Mojoroto 4 Kota Kediri. 


\section{Metode}

Penelitian ini termasuk pada jenis penelitian tindakan kelas yang memiliki beberapa tahap. Penelitian ini dilaksanakan pada SDN Mojoroto 4 Kota Kediri siswa kelas IV. Penelitian tindakan kelas adalah penelitian yang dilakukan dengan memberikan tindakan guna untuk memberikan solusi terhadap suatu masalah. Penelitian tindakan kelas menurut (Putria, 2017) adalah tentang mengintegrasikan beberapa prosedur penelitian dengan Tindakan untuk memberikan perbaikan atau solusi. Begitu juga menurut Arikunto dalam (Putria, 2017) memiliki desain penelitian terdiri dari 4 macam di antaranya adalah planning yang berarti perencanaan, acting yang berarti tindakan, pengamatan yang berarti observing, dan terakhir adalah reflecting yang berarti refleksi. Seperti pada gambar di bawah ini.

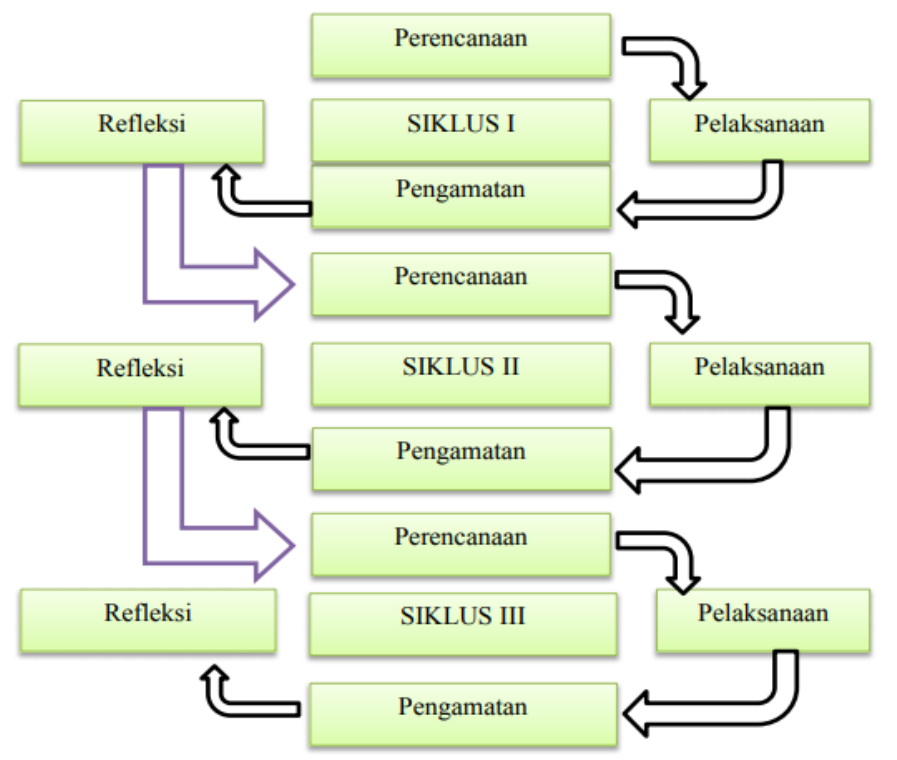

Gambar 1. Desain penelitian Arikunto dalam (Putria, 2017)

Penelitian Tindakan kelas memiliki prosedur penelitian, yang merupakan langkah yang digunakan untuk melakukan penelitian dimulai dari perencanaan hingga akhirnya suatu penelitian itu sendiri. Prosedur penelitian ini adalah terdiri dari pra siklus hingga siklus 3. Di mana pada setiap siklus terdapat perencanaan, pelaksanaan, pengamatan, dan refleksi.

\section{Hasil}

Peneliti menggunakan Blended Media Sinkronus dan Media Asinkronus ini adalah gabungan dari media sinkronus dan media asinkronus. Penggabungan media seperti zoom, google classroom, quisis, google form saat proses pembelajaran. Blended Media Sinkronus dan Media Asinkronus sangat efektif digunakan saat proses pembelajaran di masa pandemi sesuai dengan kebutuhannya. Diperkuat dengan pernyataan (Fahmi, 2020) bahwa penggunaan media sinkronus dan asinkronus digunakan saat proses pembelajaran sesuai dengan kebutuhan dan aplikasi tersebut dapat melengkapi satu sama lain.

Pada saat penelitian di SDN Mojoroto 4 Kota Kediri. Peneliti menggunakan media asinkronus berupa WhatsAap saja disamakan dengan pra siklus namun terdapat tambahan berupa power point untuk mendapatkan hasil belajar siswa melalui soal yang diberikan pada media power point yang diberikan melalui whatsaAo group. Kemudian pada siklus 1 menggunakan media sinkronus berupa zoom dan media 
asinkronus berupa google formulir. Pada siklus 3 media sinkronus berupa zoom dan media asinkronus berupa quisis. Dari menggunakan media blended asinkronus dan sinkronus didapatkan hasil bahwa dapat meningkatan hasil belajar siswa. Dengan rata-rata terdapat kenaikan persiklus dan hasil yang didapatkan terakhir pada siklus 2 ke siklus 3 sudah hampir 50\% dari hasil yang sudah lulus KKM pada siklus 2 yaitu 10 dan hasil yang sudah lulus KKM pada siklus 3 adalah 18. Berikut bentuk diagram dari penggunaan Blended Media Sinkronus dan Media Asinkronus di SDN Mojoroto 4 Kota Kediri.

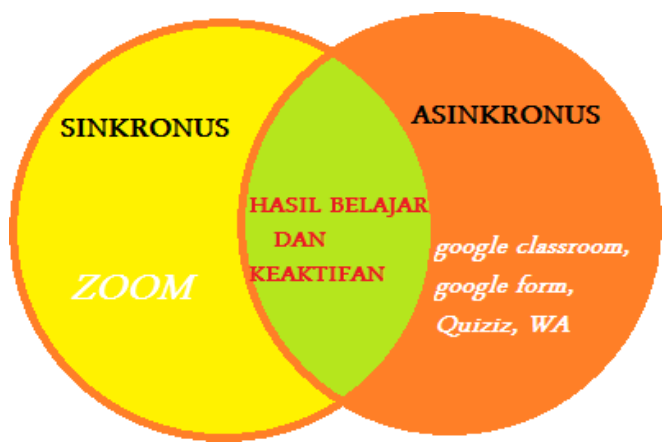

Gambar 2. Penggunaan Blanded Media sinkronus dan Media asinkronus.

Penggunaan media sinkronus yaitu zoom yang digunakan untuk memberikan materi melalui tatap muka secara langsung dan mengetahui keaktifan siswa secara langsung serta mengolah daya pikirnya untuk tetap berpikir kritis selama pandemi ini agar tidak menurun ketika ada pandemi. Sedangkan pada penggunaan asinkronus ini digunakan setelah selesai pembelajaran secara tatap muka ataupun saat tatap muka berlangsung dengan tujuan guru tetap mengawasi dan memandu siswa dalam mengerjakan tugas serta saat dalam menggunakan aplikasi. Berikut waktu saat menggunakan media sinkronus dan asinkronus saat penelitian.

Tabel 1. Waktu Penggunaan Blended Media Sinkronus dan Media Asinkronus

\begin{tabular}{cc}
\hline Siklus & Blanded media asinkronus dan sinkronus \\
\hline 1 & Whatsaap + powerpoint \\
\hline 2 & Zoom dan google form \\
\hline 3 & Zoom dan quisis \\
\hline
\end{tabular}

Penggunaan media asinkronus dan sinkronus yang berbeda disetiap siklus penelitian dapat memberikan pengetahuan yang baru untuk siswa dan orang tua. Penggunaan media yang berbeda juga dapat memberikan peningkatan hasil belajar.

Pada saat penelitian ini proses mengambil data dan untuk mendapatkan hasil yaitu pada proses prasiklus adalah di mana peneliti mendapatkan hasil dari yang didapatkan sebelum adanya tindakan solusi dalam penelitian yang ada pada pembelajaran, siklus 1 peneliti menggunakan media Whatsaap untuk menerangkan materi pembelajaran namun dimodifikasi dengan tambahan menggunakan media tambahan lainnya yaitu Power Point yang terdapat soal diberikan sehingga peneliti mendapatkan hasil belajar. Pada saat refleksi didapatkan bahwa hasilnya kurang maksimal maka dilanjutkan dengan penelitian siklus 2. Pada siklus 2 peneliti menggunakan Google Form untuk mendapatkan hasil nilai. Pada saat refleksi didapatkan bahwa haislnya kurang maksimal maka dilanjutkan dengan penelitian siklus 3. Pada siklus 3 peneliti menggunakan quisis untuk mendapatkan hasil nilai. Pada penelitian ini menghasilkan bahwa terdapat peningkatan hasil belajar siswa dapat dilihat pada setiap siklus. Berikut hasil dari hasil belajar siswa setiap siklus yaitu pada saat pra siklus didapatkan siswa yang belum lulus KKM sebanyak 12 orang 
dan siswa yang lulus KKM sebanyak 9 orang. Pada saat siklus 1 didapatkan siswa yang belum lulus KKM sebanyak 14 orang dan siswa yang lulus KKM sebanyak 7 orang. Pada saat siklus 2 didapatkan siswa yang belum lulus KKM sebanyak 11 orang dan siswa yang lulus KKM sebanyak 10 orang. Pada saat siklus 3 didapatkan siswa yang belum lulus KKM sebanyak 3 orang dan siswa yang lulus KKM sebanyak 18 orang. Lebih jelas terlihat pada gambar 1 berikut ini.

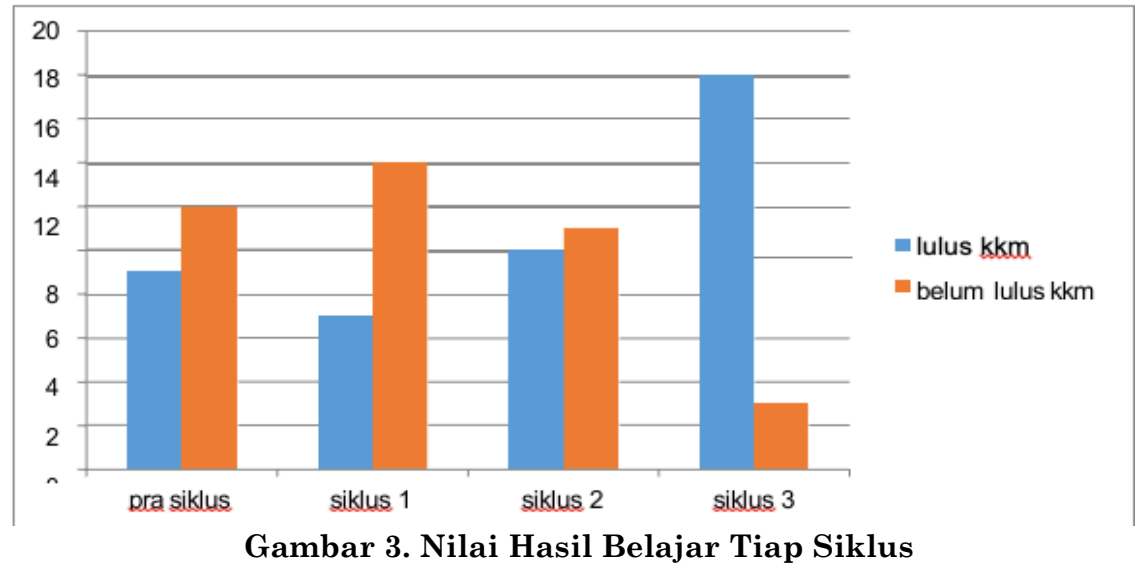

Pada saat pra siklus ke siklus 1 terdapat penurunan hasil belajar siswa karena siswa yang tidak mendengarkan dan memperhatikan instruksi guru. kemudian terdapat peningkatan anatara siklus 1 ke siklus ke 2 . Namun peningkatannya belum maksimal apa yang diharapkan peneliti, karena peneliti ingin mendapatkan hasil mendekati $50 \%$ peningkatannya. Sehingga peneliti meneruskan penelitian pada siklus 3 . Pada siklus ke 2 ke siklus ke 3 didapatkan hasil pada peningkatan hasil belajar yang signifikan. Dapat disimpulkan bahwa penelitian ini dapat memberikan solusi dalam peningkatan hasil belajar siswa. Diperkuat dengan penelitian (Utami, 2014) bahwa pada penelitiannya berhasil meningkatkan hasil belajar siswa melalui media komputer.

\section{Pembahasan}

\section{Kondisi Penelitian}

\section{Pra Siklus}

Pada penelitian ini dapat diketahui juga bahwa hasil belajar siswa sebelum adanya penelitian ini diperoleh $57 \%$ atau sebanyak 12 siswa yang tidak lulus KKM. Sedangkan yang lulus KKM hanya $43 \%$ atau 9 siswa. Dilihat pada diagram di bawah ini.

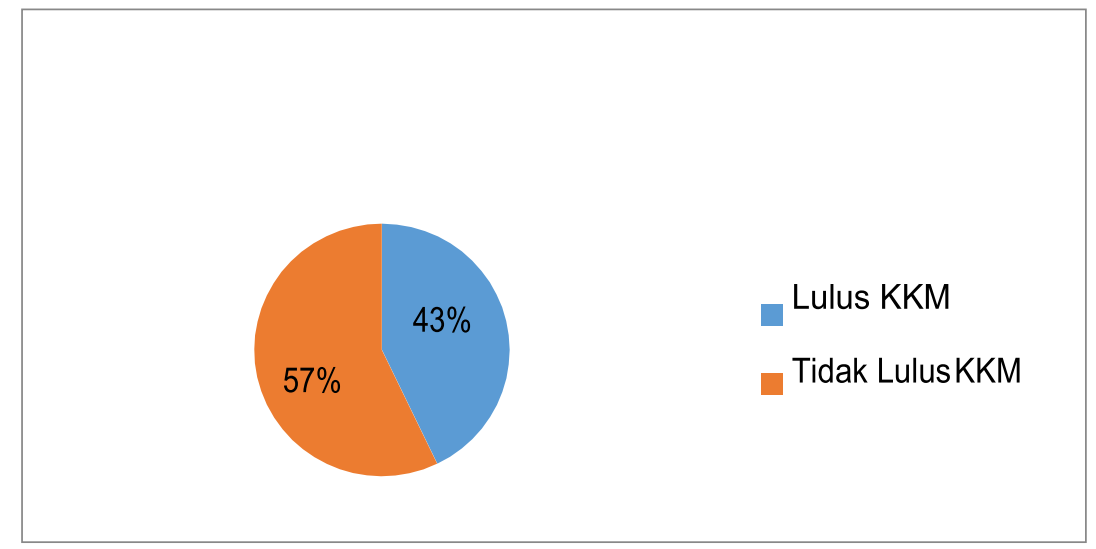

Gambar 4. Nilai Hasil Belajar 
Nilai yang tidak lulus KKM sebanyak 57\% dan yang lulus hanya 43\% sehingga dibuat penelitian pada siklus 1 . Peneliti mengamati pada pra siklus ini didapatkan bahwa permasalahan terletak pada penggunaan media asinkronus satu saja yaitu whatsapp. Mnurut (Khasanah dkk, 2021) bahwa penggunaan whatsAap dalam pembelajaran daring kurang efektif karena guru yang kurang menguasai fitur, kurangnya pengawasan terhadap siswa, dan siswa yang kurang memahami materi disampaikan guru. Dengan penggunaan satu media asinkronus yaitu whatsapp belum cukup untuk melihat nilai keaktifan siswa sehingga hanya beberapa indikator yang terlihat dan tidak cukup maksimal pada nilai yang didapat serta hanya beberapa siswa saja yang aktif. Disimpulkan bahwa nilai keaktifan siswa menurun. Begitu juga pada nilai hasil belajar siswa yang menurun. Hal ini dikarenakan karena siswa yang tidak memperoleh penjelasan guru secara langsung dan banyak siswa yang tidak mengumpulkan tugas karena tidak memperhatikan instruksi dari guru. (Daheri, 2020) bahwa penggunaan whatsAap dalam pembelajaran sangat tidak efektif karena kurangnya penjelasan dari guru, rendahnya atau terdapat kekurangan dalam aspek keterampilan dan sikap, latar belakang pendidikan orang tua, dan sinyal internet. Oleh karena itu, selanjutnya untuk memberikan solusi maka dilakukanlah penelitian dengan dimulai pada siklus 1 .

\section{Siklus 1}

Pada siklus 1 pembelajaran dilaksanakan seperti pembelajaran sebelumnya ketika belum adanya penelitian yaitu dengan menggunakan whatsapp sebagai pemberian materi dan tugas melalui group whatsapp. Namun bedanya peneliti memberikan tambahan dalam kegiatan pembelajaran yaitu memberikan pertanyaan sebagai tanda kehadiran siswa dan sebagai bahan diskusi melalui power point (PPT). Menurut (Wahyuni, 2021) bahwa dengan menggunakan whatsaAp guru tetap memberikan strategi agar siswa keluar dari zona nyamnnnya yaitu dengan membuat materi pembelajaran yang sangat sederhana agar mudah dimengerti, terdapat jangka waktu dalam pengumpulan tugas, dan dilakukan terdapat interaksi atau diskusi dalam pembahasan yang ada. Selain itu alasan tetap menggunakan media whatsapp ini agar peneliti mengetahui secara detail permasalahan walaupun sudah dilakukan modifikasi terhadap pembelajaran dengan melakukan penelitian penambahan waktu dalam pengumpulan tugas dan strategi lainnya seperti penambahan power point. Adapun tahap-tahap yang dilakukan peneliti adalah sebagai berikut.

a. Perencanaan

1) Membuat perangkat pembelajaran yang digunakan saat mengambil data di kelas.

2) Menentukan media yang digunakan yaitu whatsapp untuk pemberian materi dan pemberian tugas.

3) Peneliti merangkum materi pada PPT yang nantinya akan diberikan kepada siswa. Namun pada PPT ini masih banyak tulisan terkait materi yang diberikan.

b. Pelaksanaan

1) Guru dan siswa melaksanakan proses pembelajaran.

2) Guru membuka pembelajaran, pemberian materi, pemberian tugas, dan penutup melalui group whatsapp.

3) Materi berupa PPT yang dikirimkan kepada siswa.

4) Siswa memahami dan mempelajari PPT yang diberikan guru.

5) Siswa diberikan tugas atau berupa pertanyaan sebagai bukti kehadiran yang dikirimkan melalui whatsapp sebagai bahan diskusi tentang materi gaya, gerak, hubungan gaya dan gerak, tokoh dan perwatakan.

6) Siswa mengirimkan tugas dengan batas waktu yang telah ditentukan.

7) Guru memberikan kesimpulan dan pembahasan terkait materi yang diberikan. c. Pengamatan

1) Guru menilai hasil belajar siswa melalui tugas yang diberikan oleh guru melalui whatsapp. Dapat diperoleh bahwa hasil belajar siswa pada siklus 1 diperoleh 
$67 \%$ atau sebanyak 14 siswa yang tidak lulus KKM. Sedangkan yang lulus KKM hanya $33 \%$ atau 7 siswa. Dilihat pada diagram di bawah ini,

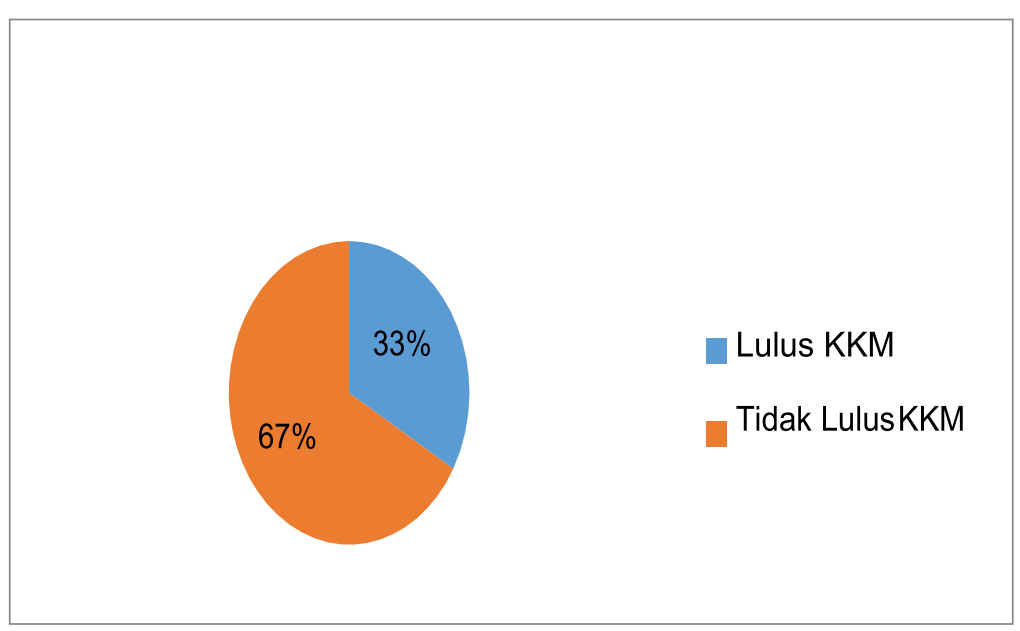

Gambar 5. Nilai Hasil Belajar

2) Guru mengamati hasil belajar yang didapatkan siswa. Dalam pengamatan guru, hasil belajar siswa yang hanya memperoleh $67 \%$ atau sebanyak 14 siswa yang tidak lulus KKM. Sedangkan yang lulus KKM hanya $33 \%$ atau 7 siswa dikarenakan siswa yang tidak menegrjakan tugas yangdiberikan sebagai nilai penugasan. Sehingga dapat dikatakan bahwa dalam pembelajaran daring menggunakan media sinkronus whatsapp tidak berjalan degan baik pada proses pembelajaran karena hasil belajar menurun walaupun cara dalam kegiatan pembelajaran dirubah ataupun ditambah. Menuryt (Asiyah, 2021) bahwa dengan menggunakan media pembelajaran whatsaAp tidak menjadi efektif dalam memberikan materi karena guru tidak dapat memantau siswa secara langsung, kurangnya interaksi, dan hambatan sinyal. Untuk itu peneliti yakin pada siklus ke 2 memulai menggunakan media blended sinkronus dan asinkronus.

d. Refleksi

Dengan tidak adanya peningkatan hasil belajar dan keaktifan siswa. Maka penelitian dilanjutkan pada siklus 2 .

\section{Siklus 2}

Pada siklus 2 pembelajaran dilaksanakan melalui pengembangan siklus 1 yaitu dengan menggunakan zoom sebagai pemberian materi dengan tatap muka secara langsung virtual. Kemudian untuk pemberian tugas menggunakan google form yang mana siswa bisa melihat nilainya secara langsung. Adapun tahap-tahap yang dilakukan peneliti adalah sebagai berikut.

a. Perencanaan

1) Membuat perangkat pembelajaran yang digunakan saat mengambil data di kelas siklus berikutnya.

2) Menentukan media yang digunakan yaitu zoom untuk pemberian materi dan google form untuk pemberian tugas.

3) Peneliti merangkum materi pada PPT yang nantinya akan diberikan kepada siswa. namun pada PPT ini adanya video pembelajaran di dalamnya dan ada sedikit materinya.

b. Pelaksanaan

1) Guru dan siswa melaksanakan proses pembelajaran.

2) Guru mengirim link zoom.

3) Guru mengabsen kehadiran siswa melalui zoom.

4) Guru mengshare screen materi berupa PPT yang ditampilkan kepada siswa.

5) Siswa memahami dan mempelajari PPT yang ditampilkan melalui zoom. 
6) Guru melakukan tanya jawab kepada siswa.

7) Guru memberikan pertanyaan kepada siswa untuk mengasah keterampilan siswa dan sikap melalui zoom serta saat itu juga.

8) Siswa mengkomununikasikan kepada guru dan teman- temannya.

9) Guru menutup pembelajaran.

10) Guru memberikan tugas sebagai hasil belajar melalui google form. Siswa yang tidak hadir dapat mengerjakan tugas yang diberikan melalalui link yang dibagikan.

11) Siswa mengirimkan tugas dengan batas waktu yang telah ditentukan yaitu 1 hari alasannya untuk memberikan keloanggaran saat pandemi.

12) Siswa mengetahui hasil yang diperoleh dan mengetahui salah dan benar saat menjawab melalui google form karena di setting siswa dapat melihat skor dan pertanyaan mengacak secara otomatis.

13) Guru memberikan kesimpulan dan pembahasan terkait materi yang diberikan.

c. Pengamatan

1) Guru menilai hasil belajar siswa melalui tugas yang diberikan oleh guru melalui google form. Dapat diperoleh bahwa hasil belajar siswa pada siklus 2 diperoleh $52 \%$ atau sebanyak 11 siswa yang tidak lulus KKM. Sedangkan yang lulus KKM hanya $48 \%$ atau 10 siswa. Dilihat pada diagram di bawah ini:

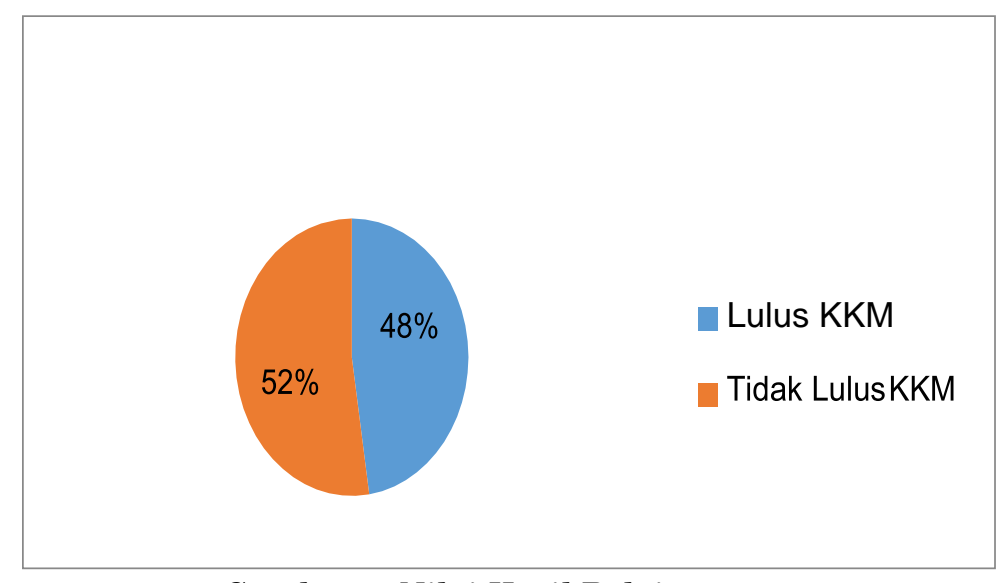

Gambar 6. Nilai Hasil Belajar

2) Guru mengamati hasil belajar melalui tugas yang dikumpulkan. Dalam pengamatan guru, hasil belajar siswa yang hanya memperoleh pada siklus 2 diperoleh $52 \%$ atau sebanyak 11 siswa yang tidak lulus KKM. Sedangkan yang lulus KKM hanya $48 \%$ atau 10 siswa. Sudah terdapat peningkatan dari siklus 1 dan 2. Siswa sudah dapat dilihat pada keaktifannya yang mengerti melalui penjelasan materi guru secara langsung dengan zoom sehingga berdampak pada peningkatan hasil belajar. Menurut (Kuntarto dkk, 2021) bahwa dalam pembelajaran daring menggunakan zoom dapat memberikan manfaat di antaranya adalah memudahkan memahami materi yang disampaikan oleh guru, meningkatkan motivasi dalam pembelajaran daring, siswa menjadi tidak bosan dan guru merasakan sangat efektif dalam pembelajaran daring menggunakan zoom. Sehingga dapat dikatakan bahwa dalam pembelajaran daring menggunakan blended media asinkronus dan media sinkronus zoom dan google form berjalan degan baik pada proses pembelajaran karena hasil d. Refleksi belajar mulai meningkat.

Hasil belajar dan keaktifan siswa sudah meningkat pada siklus ke 2, namun peneliti masih belum puas karena nilai peningkatan belum terlihat secara signifikan sehingga peneliti melakukan penelitan berikutnya yaitu pada siklus ke 3 . 


\section{Siklus 3}

Pada siklus 3 pembelajaran dilaksanakan melalui pengembangan siklus 2 yaitu dengan menggunakan zoom sebagai pemberian materi dengan tatap muka secara langsung virtual. Kemudian untuk pemberian tugas menggunakan quiziz yang mana siswa bisa melihat nilainya secara langsung dan mengetahui kunci jawaban serta guru dan siswa bisa berdiskusi di ruang zoom karena dipantau dan dipandu secara langsung. Adapun tahap-tahap yang dilakukan peneliti:

a. Perencanaan

1) Membuat perangkat pembelajaran yang digunakan saat mengambil data di kelas siklus berikutnya.

2) Menentukan media yang digunakan yaitu zoom untuk pemberian materi dan quiziz untuk pemberian tugas.

3) Peneliti merangkum materi pada PPT yang nantinya akan diberikan kepada siswa. Namun pada PPT ini full dengan video pembelajaran.

b. Pelaksanaan

1) Guru dan siswa melaksanakan proses pembelajaran.

2) Guru mengirim link zoom.

3) Guru mengabsen kehadiran siswa melalui zoom.

4) Guru share screen Materi berupa PPT yang dikirimkan kepada siswa.

5) Siswa memahami dan mempelajari PPT yang dishare guru.

6) Guru tanya jawab kepada siswa.

7) Guru memberikan pertanyaan yang mengasah keterampilan siswa dan sikap melalui zoom serta saat itu juga.

8) Siswa mengkomununikasikan kepada guru dan teman-temannya.

9) Guru memberikan tugas sebagai hasil belajar melalui quiziz. Link dibagikan di group wa.

10) Guru memantau dan memandu secara langsung saat di ruang zoom sehingga siswa dan guru bisa diskusi bersama.

11) Jika ada siswa yang tidak masuk tetap bisa mengerjakan tugas.

12) Siswa mengirimkan tugas dengan batas waktu yang telah ditentukan yaitu 1 hari sebagai kelonggaran saat pandemi.

13) Siswa mengetahui hasil yang diperoleh dan mengetahui kunci jawaban.

14) Guru memberikan kesimpulan dan pembahasan terkait materi yang diberikan.

15) Guru menutup pembelajaran.

c. Pengamatan

1) Guru menilai hasil belajar siswa melalui tugas yang diberikan oleh guru melalui quiziz. Dapat diperoleh bahwa hasil belajar siswa pada siklus 3 diperoleh 14\% atau sebanyak 3 siswa yang tidak lulus KKM. Sedangkan yang lulus KKM hanya $86 \%$ atau 18 siswa. Dilihat pada diagram di bawah ini:

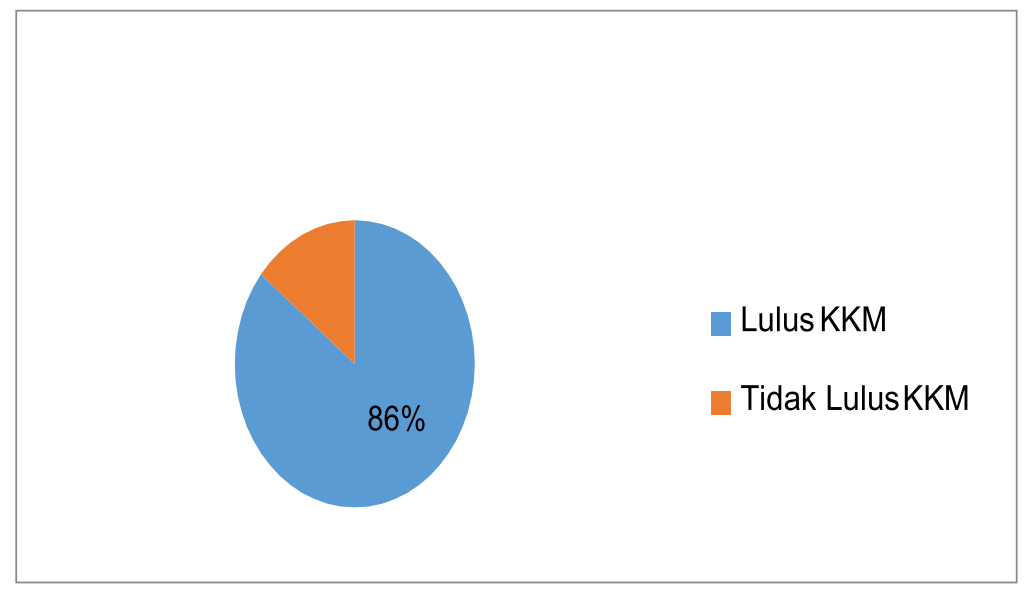

Gambar 7. Nilai Hasil Belajar 
2) Guru mengamati hasil belajar melalui tugas yang dikumpulkan. Dalam pengamatan guru, hasil belajar siswa yang hanya memperoleh pada siklus 3 diperoleh $14 \%$ atau sebanyak 3 siswa yang tidak lulus KKM. Sedangkan yang lulus KKM hanya $86 \%$ atau 18 siswa. tetap mengalami peningkatan dari siklus 2 dan 3. Siswa sudah dapat dilihat pada keaktifannya yang mengerti melalui penjelasan materi guru secara langsung dengan zoom sehingga berdampak pada peningkatan hasil belajar. Sehingga dapat dikatakan bahwa dalam pembelajaran daring menggunakan blended media asinkronus dan media sinkronus zoom dan quiziz berjalan degan baik pada proses pembelajaran karena hasil belajar mengalami peningkatan secara signifikan. Diperkuat dengan menurut (Widyasari, 2021) bahwa terdapat peningkatan hasil belajar siswa dengan menggunakan media pembelajaran berbasis blended media asinkronus dan sinkronus dalam pembelajaran daring jarak jauh yang dilakukan.

d. Refleksi

Pada pra siklus ke siklus pertama untuk peningkatan keaktifan dan hasil belajar belum ada peningkatan. Untuk siklus pertama ke siklus kedua dapat adanya peningkatan untuk keaktifan siswa dan sudah adanya peningkatan untuk hasil belajar tapi belum signifikan. Sehingga peneliti ingin melanjutkan penelitian lagi ke siklus ketiga. Pada siklus kedua ke siklus ketiga terdapat peningkatan yang signifikan baik keaktifan siswa maupun hasil belajar siswa. Peneliti sudah merasa cukup dengan hasil peningkatan yang signifikan, sehingga penelitian dihentikan pada siklus ke 3 .

\section{Simpulan}

Penggunaan Blanded Media Sinkronus dan Asinkronus pada saat proses pembelajaran dengan dilakukan secara bergantian yang digunakan. Dengan demikian dapat memperoleh hasil yaitu terdapat peningkatkan hasil belajar siswa dengan menggunakan Blanded Media Sinkronus dan Asinkronus. Dengan penggunaan media sinkronus digunakan sebagai pemberian materi tatap muka secara langsung dengan cara virtual. Kemudian untuk media asinkronus digunakan untuk mengerjakan tugas yang diberikan guru.

\section{Saran}

Semoga penelitian ini tidak berhenti hanya pada penggunaan media blended sinkronus dan asinkronus saja melainkan diberi inovasi lagi seperti menggunakan media berbasis IT lainnya. Untuk kendala sinyal dan gadget berharap dapat perhatian lebih dari pemerintah.

\section{Referensi}

Adi, et. al. (2021). Dampak Positif dan Negatif Pembelajaran Jarak Jauh di Masa Pandemi Covid-19. Jurnal Ilmiah Pendidikan \& Pembelajaran, 5(1), 43-48.

Amadea, K., \& Ayuningtyas, M. D. (2020). Perbandingan Efektivitas Pembelajaran Sinkronus dan Asinkronus Pada Materi Program Linear. Primatika: Jurnal Pendidikan Matematika, 9(20), 111-120.

Asiyah, D. (2021). Pemanfaatan Aplikasi WhatsaAp sebagai Media dalam Pembelajaran di Sekolah Dasar Negeri 116/X Lambur II Kabpaten Tanjung Jabung Timur. Skripsi. UIN Sulthan Thaha Saifuddin.

Daheri, M.,et.al. (2020). Efektifitas WhatsaAp sebagai Media Pembelajaran Daring. Jurnal Basicedu, 4(4), 775-783.

Fahmi, M. H. (2020). Komunikasi Synchronous Dan Asynchronous Dalam E-Learning Pada Masa Pandemic Covid-19. Jurnal Nomosleca, 6(2), 146-158. 
Keputusan Kepala Badan Nasional Penanggulangan Bencana Nomor 13 A Tahun 2020 Tentang Perpanjangan Status Keadaan Tertentu Darurat Bencana Wabah Penyakit Akibat Virus Corona Di Indonesia

Khasanah, dkk. (2021). Efektifitas Media WhatsaAp Group Dalam Pembelajaran Daring. Jurnal Teknologi Pendidikan, 10(1), 47-65.

Kuntarto, dkk. (2021). Analisis Manfaat Penggunaan Aplikasi Zoom dalam Pembelajaran Daring bagi Guru dan Siswa di Sekolah Dasar. Jurnal Pendidikan Dasar Nusantara, 7(1), 2569-6461.

Lestari, W. (2021). Pemanfaatan Whatsapp Sebagai Media Pembelajaran Dalam Jaringan Masa Pandemi Covid-19 Di Kelas VI Sekolah Dasar. Journal of Chemical Information and Modeling, 53(9), 1689-1699.

Menteri Pendidikan dan Kebudayaan. 17 Maret 2020. Surat Edaran Menteri Pendidikan dan Kebudayaan nomor 36962/ MPK.A/HK2020.TentangPembelajaransecara daring dan BekerjadariRumahdalamRangkaPencegahanPenyebaran Corona Virus Disease (Covid-19)

Santaria, R. (2020). Dampak Pandemi Covid-19 terhadap Proses Pengajaran bagi Guru dan Siswa Pendahuluan. 3(2), 289-295.

Utami, M. S. (2014). Upaya Peningkatan Hasil Belajar Siswa Melalui Media Komputer Pada Materi Peninggalan Sejarah Hindu Budha di Indonesia Kelas V SDN Kepatihan 04 Kaliwates Jember Tahun Pelajaran 2012/2013. Jurnal Pancaran, 3(4), 175-182.

Putria, Y.D.(2017).Penerapan Model Kooperaif Tipe TalkingStick Untuk Meningkatkan Hasil Belajar Siswa Pada Subtema Pelestarian Lingkungan (Penelitian Tindakan Kelas Terhadap Siswa Kelas V SdnMuararajeun Kota Bandung Tahun Ajaran 2016/2017). Skripsi(S1) thesis, FKIP UNPAS.

Wahyuni, L. (2021). Penggunaan Aplikasi WhatsaAp dalam Pembelajaran Daring di Kelas IV A SDN 61 Bengkulu Selatan. Skripsi. IAIN Bengkulu.

Widyasari, L.A. \& Mohammad, A.R. (2021). Apakah Penerapan Blended Learning Dapat Meningkatkan Motivasi dan Hasil Belajar Siswa dalam Pembelajaran Jarak Jauh?. Jurnal Ilmu Pendidikan, 3(3), 854-864. 